\title{
Filtering Brackish Water by Photovoltaic-Powered Membrane
}

\author{
Kelvii Wei Guo* and Hon Yuen Tam
}

\begin{abstract}
Department of Mechanical and Biomedical Engineering, City University of Hong Kong, 83 Tat Chee Avenue, Kowloon Tong, Kowloon, Hong Kong
\end{abstract}

\begin{abstract}
Photovoltaic-powered membrane was taken to filter brackish water. Effect of ammonia concentration, pressure and salinity on ammonia and total dissolved solids (TDS) removal, water recovery and energy consumption had been investigated.

Results show that ammonia concentration did not influence ammonia and TDS removal, water recovery, and energy consumption obviously. Results of ammonia concentration of 10,20 and $35 \mathrm{mg} / \mathrm{l}$ were similar to that of $5 \mathrm{mg} / \mathrm{l}$. For salinity, the better filtration was achieved when the concentration of salinity was lower. With increment of pressure, ammonia and TDS removal increased simultaneously. The ammonia and TDS removal of more than $98 \%$ attained with the water recovery of $40.6 \%$ at the energy consumption of $2.0 \mathrm{kWh} / \mathrm{m}^{3}$.

It illustrates that salinity and pressure were definitely crucial to brackish water filtration with photovoltaic-powered membrane.
\end{abstract}

Keywords: Photovoltaic-powered membrane, Reverse osmosis, Brackish water, Salinity, Total dissolved solids (TDS), Energy consumption.

\section{INTRODUCTION}

Due to an urgent attempt to alleviate fossil fuel usage and $\mathrm{CO}_{2}$ emissions, renewable energy gives the enormous promising applications for energy predicted for the future, which is economic, energetically efficient, environmentally friendly and without unsustainable use of the current fossil fuel and its successive greenhouse gas production [1].

For desalination, renewable energy is a very attractive proposition, addressing both environmental concerns and the more general need for long-term sustainability [2]. More specifically, solar photovoltaicpowered reverse osmosis (PV-RO) is considered one of the more promising technology combinations [3], especially in remote areas without grid electricity or good supplies of petrol or diesel [4].

To date, although PV-RO systems operating from brackish water are already commercially available and further developments are ongoing, operation from seawater is more challenging from an energy perspective, and early demonstrations tended to require large PV arrays, making them commercially unattractive [5-7].

Therefore, aim to investigate the potential of solar energy development for water filtration/desalination in Hong Kong, a RO desalination system driven by

${ }^{*}$ Address correspondence to this author at the Department of Mechanical and Biomedical Engineering, City University of Hong Kong, 83 Tat Chee Avenue, Kowloon Tong, Kowloon, Hong Kong; Tel: 852-3442-4621; Fax: 852-34420172; E-mail: kelviiguo@yahoo.com photovoltaic power was designed, constructed and tested. Effect of ammonia concentration, pressure and salinity on TDS and ammonia removal, water recovery and energy consumption had been studied.

\section{MATERIALS AND METHODS}

\subsection{Brackish Water}

Samples of brackish water with TDS of 500, 1000, 2000, 4000 and $7000 \mathrm{mg} / \mathrm{l}$ were collected by mixing sea water (taken from the sea at Wu Kai Sha, Hong Kong) with daily drinking water and ammonia concentration of $5,10,20$ and $35 \mathrm{mg} / \mathrm{I}$ was adjusted by $\mathrm{NH}_{4} \mathrm{Cl}$. The operating pressure was $40,60,80$ and 100 psi, respectively.

\subsection{Solar Photovoltaic-Powered Reverse Osmosis (PV-RO) System}

The schematic diagram in Figure 1 shows the system configuration used in this work. In this configuration, an ultrafine filter and active carbon (5 $\mu \mathrm{m}$ × 10"/200 LPH for brackish water) were taken as a prefilter for pretreatment, while a $\mathrm{RO}$ removed the salt from the brackish water. Details of the relevant parameters are also labeled in Figure $\mathbf{1}$

\section{RESULTS AND DISCUSSION}

\subsection{Effect of Pressure with 30 psi}

$\mathrm{NH}_{3}$, Ammonia gas, is extremely soluble in water. It is the natural product of decay of organic nitrogen compounds. Although it is widely used and common in 


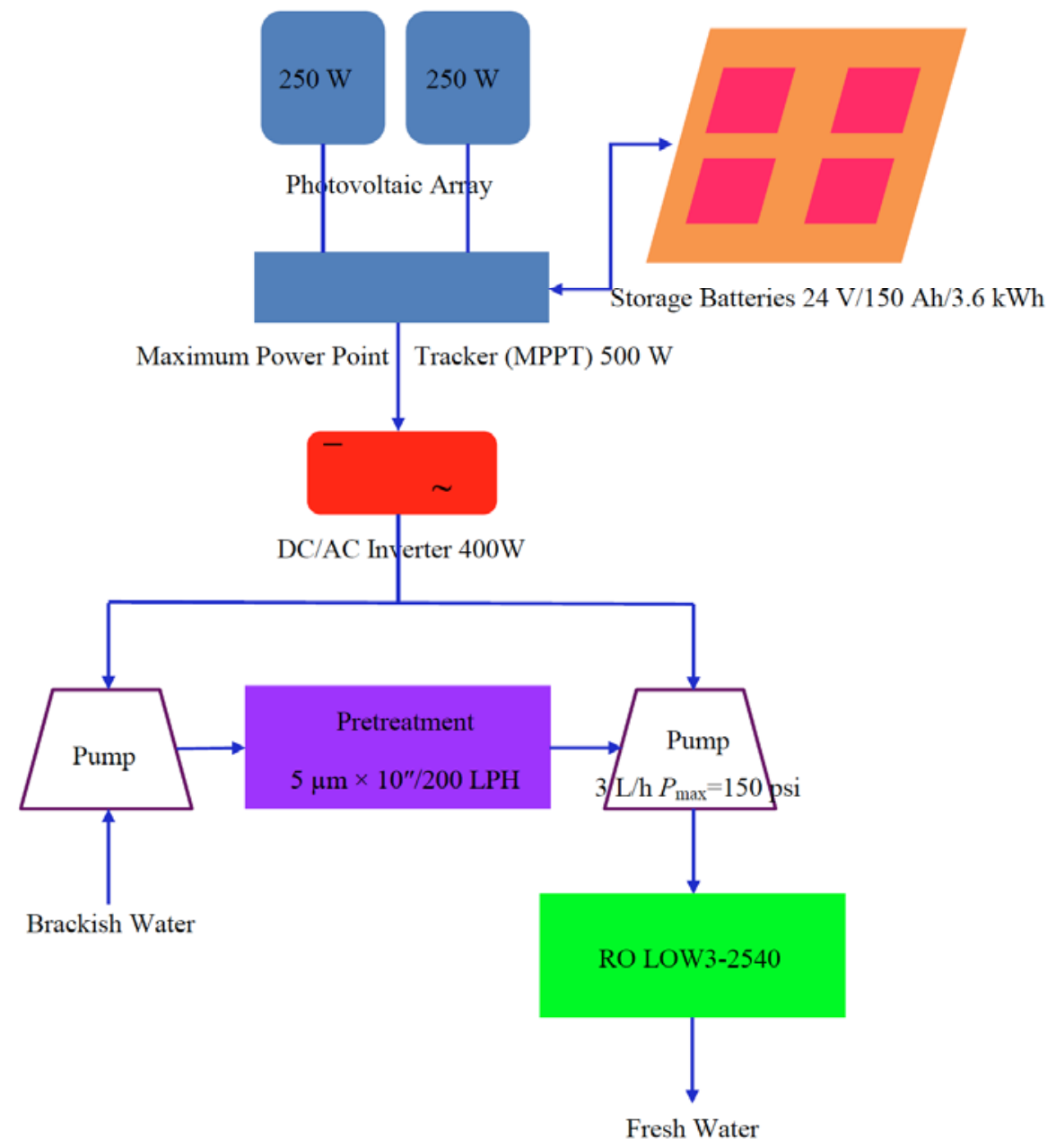

Figure 1: Schematic diagram of PV-RO system.

our society, ammonia can be both hazardous and caustic. Ammonia gets into water supplies most frequently as runoff in agricultural areas where it is applied as fertilizer and it easily finds its way into underground aquifers from animal feedlot runoff. Ammonia itself is not often found in well water because bacteria in the soil convert it to nitrates. Ammonia can be very corrosive to some copper plumbing systems. Ammonia is not regulated by current drinking water standards. Ammonia is toxic to fish and to dialysis patients. Its toxicity varies with the $\mathrm{pH}$ of the water.

Results of the ammonia removal under the different salinity concentration are shown in Figure 2. The maximum and minimum of the ammonia removal were higher than $95 \%$ and $55 \%$, respectively. The effect of ammonia concentration on ammonia removal was not impressive at the lower salinity concentration (lower than $4000 \mathrm{mg} / \mathrm{l})$. Moreover, at the higher salinity concentration, ammonia removal decreased and fluctuated distinctly with ammonia concentration increasing. It can be seen that the effect of salinity concentration on the ammonia removal was more crucial than of ammonia concentration, especially at lower concentration.

Figure 3 illustrate TDS removal variation at various ammonia concentrations under the pressure of $30 \mathrm{psi}$. It shows that the maximum of TDS removal was up to more than $96 \%$ and the minimum of TDS removal was also higher than $67 \%$. Meanwhile, with the increment of salinity concentration, TDS removal decreased, especially for higher salinity concentration. However, the effect of ammonia concentrations on TDS removal was not obvious.

Figure 4 shows the water recovery definitely decreased as the salinity concentration increased. At the same time, the effect of ammonia concentration was still not crucial. It demonstrates at lower salinity concentration, the water recovery varied obviously with the different ammonia concentration and its maximum was nearly $13 \%$. However, at higher salinity concentration, the results of the water recovery were not attractive, and the water recovery was only $0.68 \%$. 


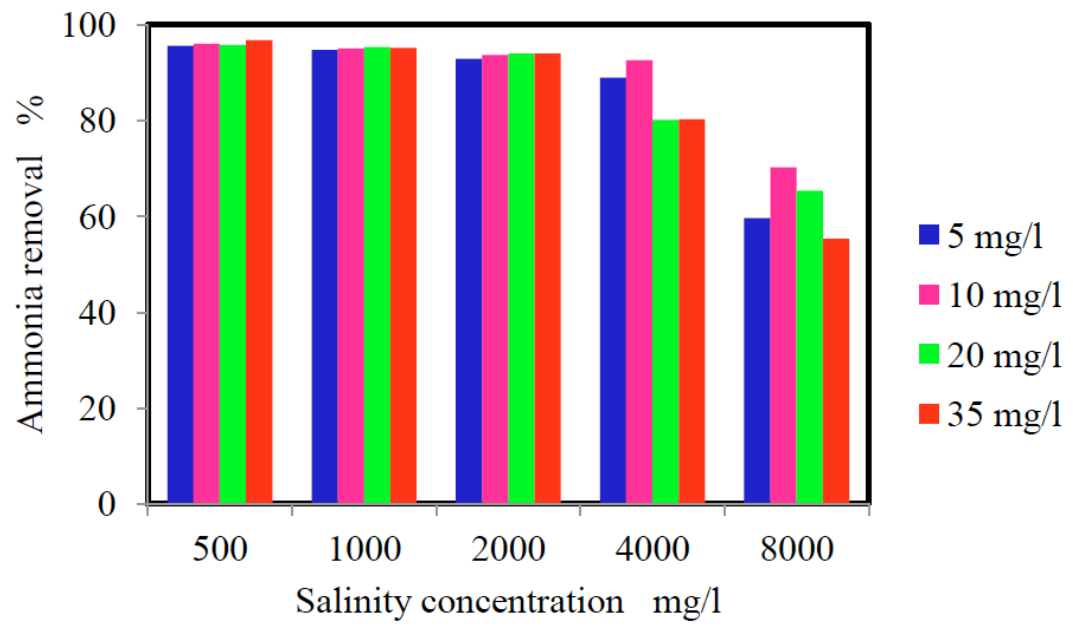

Figure 2: Relationship between ammonia removal and salinity concentration at various ammonia concentrations.

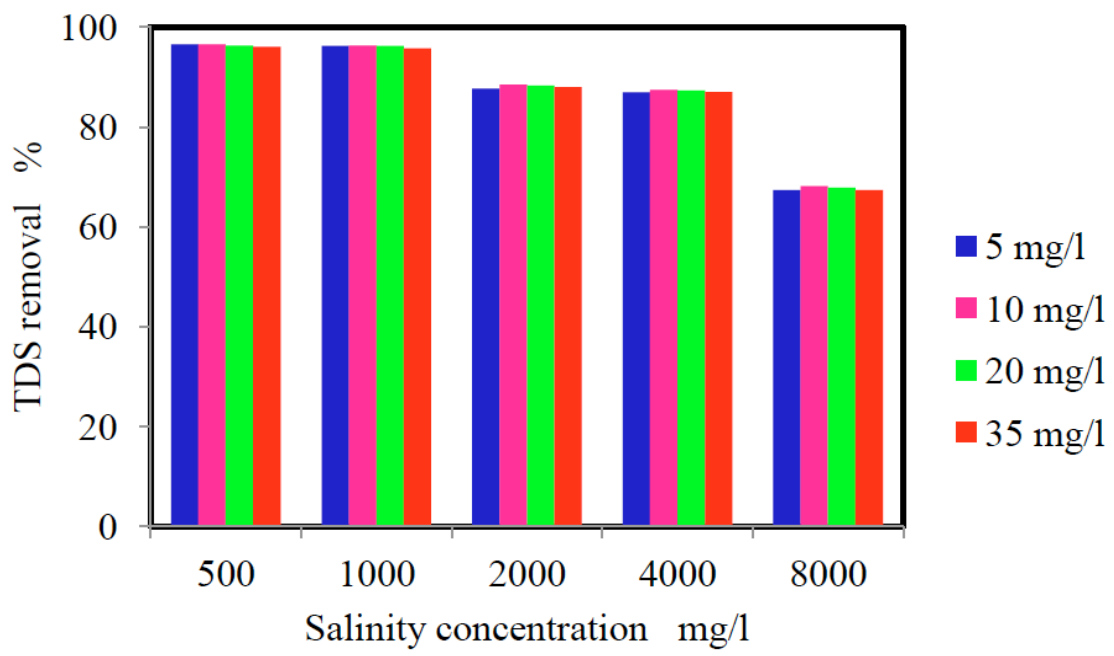

Figure 3: Relationship between TDS removal and salinity concentration at various ammonia concentrations.

Results of the energy consumption changed with the variation of salinity concentration at the different ammonia concentrations were shown in Figure 5. It depicts that at lower salinity concentration, the energy consumption at various ammonia concentrations of 5 , 10,20 and $35 \mathrm{mg} / \mathrm{l}$ was just about 3.9, 3.6, 3.9 and 4.0 $\mathrm{kWh} / \mathrm{m}^{3}$. Moreover, the change of energy consumption was not outstanding, even with higher salinity concentration. Also, with the salinity concentration increasing, the energy consumption increased simultaneously. As a result, the higher salinity concentration was, the more energy consumption needed.

\subsection{Effect of Pressure with 60,90 and 120 psi}

Results of the effect of pressure with 60, 90 and 120 psi on ammonia and TDS removal, water recovery and energy consumption are listed in Table 1. It shows the trend of ammonia and TDS removal, water recovery and energy consumption was similar to results illustrated in Figures $\mathbf{1}$ to $\mathbf{5}$. As the consequence of working pressure increment, the brackish water was desalinated effectively, especially with the salinity concentration of 500 and $1000 \mathrm{mg} / \mathrm{l}$. The ammonia, and TDS removal was higher than $98 \%$, respectively. Moreover, the water recovery was up to $40.6 \%$ with the energy consumption of $2.0 \mathrm{kWh} / \mathrm{m}^{3}$ [8]. Also, it elucidates that during desalinating brackish water with photovoltaic-powered membrane, the working pressure and salinity concentration played the significant roles, whereas ammonia concentration did not have the vitally obvious influence on ammonia and TDS removal, water recovery, and energy consumption. Results of ammonia concentration of 10,20 and 35 $\mathrm{mg} / \mathrm{l}$ were similar to that of $5 \mathrm{mg} / \mathrm{l}$. For salinity, the lower concentration was, the better filtration achieved. With the increment of pressure, ammonia and TDS removal increased simultaneously. 


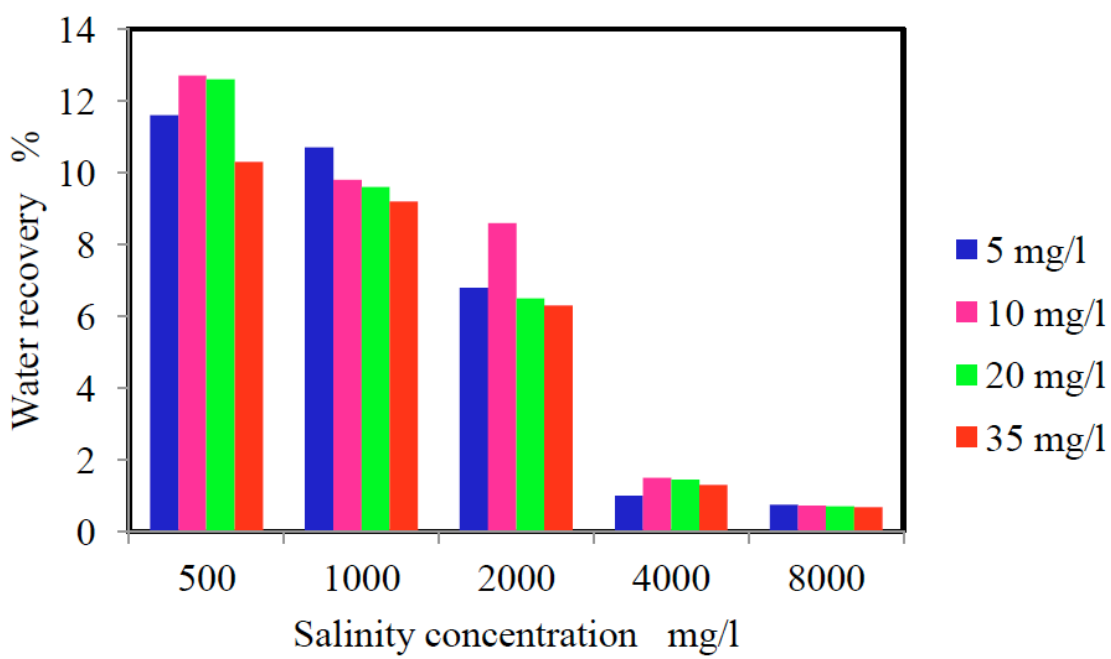

Figure 4: Relationship between water recovery and salinity concentration at various ammonia concentrations.

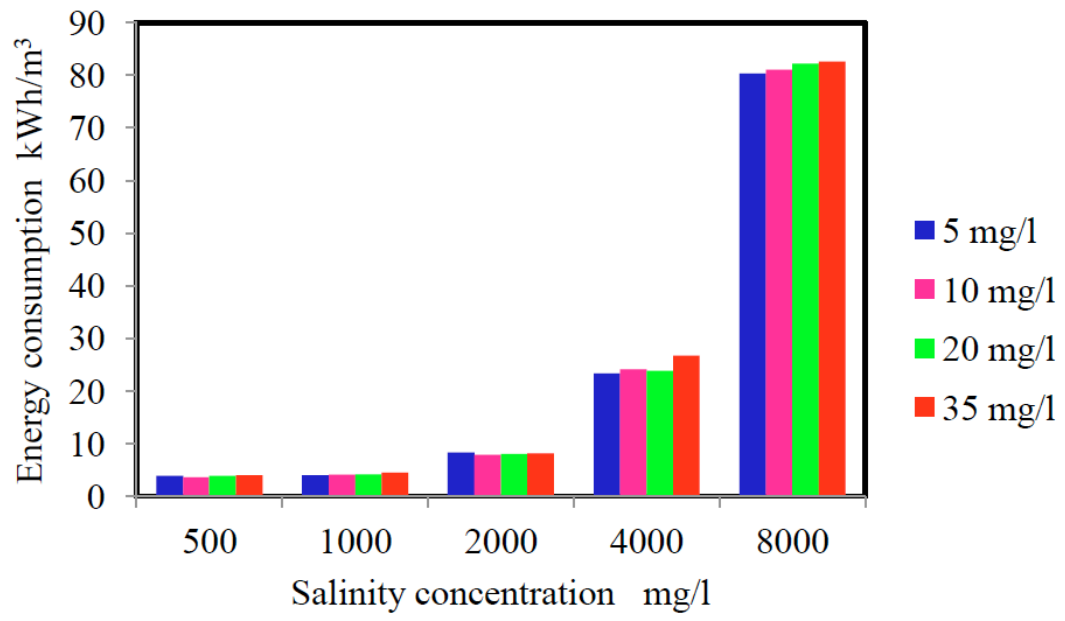

Figure 5: Relationship between energy consumption and salinity concentration at various ammonia concentrations.

Table 1: Experiment Results at Various Working Pressure

\begin{tabular}{|c|c|c|c|c|c|}
\hline \multirow[b]{3}{*}{$\begin{array}{l}\text { Pressure } \\
\text { (psi) }\end{array}$} & \multirow[b]{3}{*}{ TDS (mg/l) } & \multicolumn{4}{|c|}{ Ammonia concentration (mg/l) } \\
\hline & & \multicolumn{4}{|c|}{5} \\
\hline & & Ammonia removal (\%) & TDS removal (\%) & Water recovery (\%) & Energy consumption $\left(\mathrm{kWh} / \mathrm{m}^{3}\right)$ \\
\hline \multirow{7}{*}{30} & 500 & 95.6 & 96.5 & 11.6 & 3.9 \\
\hline & 1000 & 94.7 & 96.2 & 10.7 & 4.0 \\
\hline & 4000 & 88.9 & 86.9 & 1.0 & 23.3 \\
\hline & 8000 & 59.6 & 67.3 & 0.8 & 80.3 \\
\hline & & \multicolumn{4}{|c|}{10} \\
\hline & 500 & 96.0 & 96.5 & 12.7 & 3.6 \\
\hline & 8000 & 70.2 & 68.1 & 0.7 & 81.0 \\
\hline
\end{tabular}


(Table 1). Continued.

\begin{tabular}{|c|c|c|c|c|c|}
\hline & & \multicolumn{4}{|c|}{20} \\
\hline & 1000 & 95.3 & 96.2 & 9.6 & 4.2 \\
\hline & 2000 & 94 & 88.2 & 6.5 & 8.0 \\
\hline & 4000 & 80.1 & 87.3 & 1.5 & 23.8 \\
\hline & 8000 & 65.4 & 67.8 & 0.7 & 82.2 \\
\hline & 500 & 96.7 & 96.0 & 10.3 & 4 \\
\hline & 1000 & 95.2 & 95.7 & 9.2 & 4.5 \\
\hline & 2000 & 94.0 & 87.9 & 6.3 & 8.2 \\
\hline & 4000 & 80.3 & 87.0 & 1.3 & 26.7 \\
\hline & & \multicolumn{4}{|c|}{5} \\
\hline $\begin{array}{l}\text { Pressure } \\
\quad(p s i)\end{array}$ & TDS (mg/l) & Ammonia removal (\%) & TDS removal (\%) & Water recovery (\%) & $\begin{array}{l}\text { Energy consumption } \\
\qquad\left(\mathrm{kWh} / \mathrm{m}^{3}\right)\end{array}$ \\
\hline \multirow{18}{*}{60} & 500 & 97.8 & 97.9 & 18.7 & 3.0 \\
\hline & 1000 & 97.5 & 97.7 & 18.2 & 2.8 \\
\hline & 2000 & 94.6 & 96.8 & 13.5 & 6.1 \\
\hline & 4000 & 88.9 & 90.3 & 6.3 & 10.3 \\
\hline & 8000 & 68.1 & 69.5 & 2.2 & 29.7 \\
\hline & & \multicolumn{4}{|c|}{10} \\
\hline & & \multicolumn{4}{|c|}{20} \\
\hline & 500 & 96.8 & 97.8 & 22.8 & 2.9 \\
\hline & 1000 & 96.3 & 97.5 & 22.5 & 2.9 \\
\hline & 2000 & 94.0 & 96.1 & 12.7 & 7.7 \\
\hline & 4000 & 90.9 & 87.6 & 5.7 & 12.2 \\
\hline & 8000 & 76.1 & 70.2 & 2.2 & 32.1 \\
\hline & & \multicolumn{4}{|c|}{35} \\
\hline & 500 & 96.9 & 97.5 & 22.5 & 2.8 \\
\hline & 1000 & 96.2 & 97.3 & 22.6 & 2.7 \\
\hline & 2000 & 95.1 & 96.9 & 12.9 & 7.3 \\
\hline & 4000 & 91.1 & 89.3 & 6.2 & 12.2 \\
\hline & 8000 & 77.8 & 72.8 & 3.1 & 26.6 \\
\hline
\end{tabular}


(Table 1). Continued.

\begin{tabular}{|c|c|c|c|c|c|}
\hline \multirow[b]{3}{*}{$\begin{array}{l}\text { Pressure } \\
\quad \text { (psi) }\end{array}$} & \multirow[b]{3}{*}{ TDS (mg/l) } & \multicolumn{4}{|c|}{ Ammonia concentration $(\mathrm{mg} / \mathrm{l})$} \\
\hline & & \multicolumn{4}{|c|}{5} \\
\hline & & Ammonia removal (\%) & TDS removal (\%) & Water recovery (\%) & $\begin{array}{l}\text { Energy consumption } \\
\left(\mathrm{kWh} / \mathrm{m}^{3}\right)\end{array}$ \\
\hline \multirow{14}{*}{90} & 500 & 98.0 & 98.0 & 28.8 & 2.5 \\
\hline & 1000 & 98.0 & 97.8 & 29.0 & 2.4 \\
\hline & 4000 & 92.9 & 94.7 & 10.3 & 8.2 \\
\hline & 8000 & 78.3 & 79.6 & 3.9 & 17.3 \\
\hline & & \multicolumn{4}{|c|}{10} \\
\hline & 500 & 98.0 & 97.8 & 30.1 & 2.2 \\
\hline & 8000 & 83.4 & 85.4 & 4.1 & 26.6 \\
\hline & & \multicolumn{4}{|c|}{20} \\
\hline & 500 & 97.6 & 97.8 & 29.5 & 2.1 \\
\hline & 1000 & 97.3 & 97.5 & 29.3 & 2.3 \\
\hline & 2000 & 96.2 & 96.1 & 19.1 & 3.5 \\
\hline & 4000 & 94.1 & 95.1 & 9.8 & 8.8 \\
\hline & 8000 & 83.0 & 80.2 & 3.1 & 32.1 \\
\hline & & \multicolumn{4}{|c|}{35} \\
\hline & & \multicolumn{4}{|c|}{ Ammonia concentration $(\mathrm{mg} / \mathrm{l})$} \\
\hline & & \multicolumn{4}{|c|}{5} \\
\hline $\begin{array}{l}\text { Pressure } \\
\quad(p s i)\end{array}$ & TDS (mg/l) & Ammonia removal (\%) & TDS removal (\%) & Water recovery $(\%)$ & $\begin{array}{l}\text { Energy consumption } \\
\qquad\left(\mathrm{kWh} / \mathrm{m}^{3}\right)\end{array}$ \\
\hline \multirow{11}{*}{120} & 500 & 98.1 & 98.2 & 39.2 & 2.0 \\
\hline & 1000 & 98.0 & 98.0 & 39.7 & 2.0 \\
\hline & 2000 & 96.1 & 97.1 & 20.2 & 3.3 \\
\hline & 4000 & 94.9 & 94.7 & 10.6 & 7.9 \\
\hline & 8000 & 88.3 & 87.6 & 4.5 & 11.3 \\
\hline & & \multicolumn{4}{|c|}{10} \\
\hline & 500 & 98.2 & 97.9 & 40.5 & 2.0 \\
\hline & 1000 & 97.5 & 97.7 & 40.6 & 2.0 \\
\hline & 2000 & 97.1 & 96.5 & 28.7 & 2.3 \\
\hline & 4000 & 93.2 & 92.9 & 12.6 & 6.1 \\
\hline & 8000 & 84.5 & 84.0 & 5.8 & 9.6 \\
\hline
\end{tabular}


(Table 1). Continued.

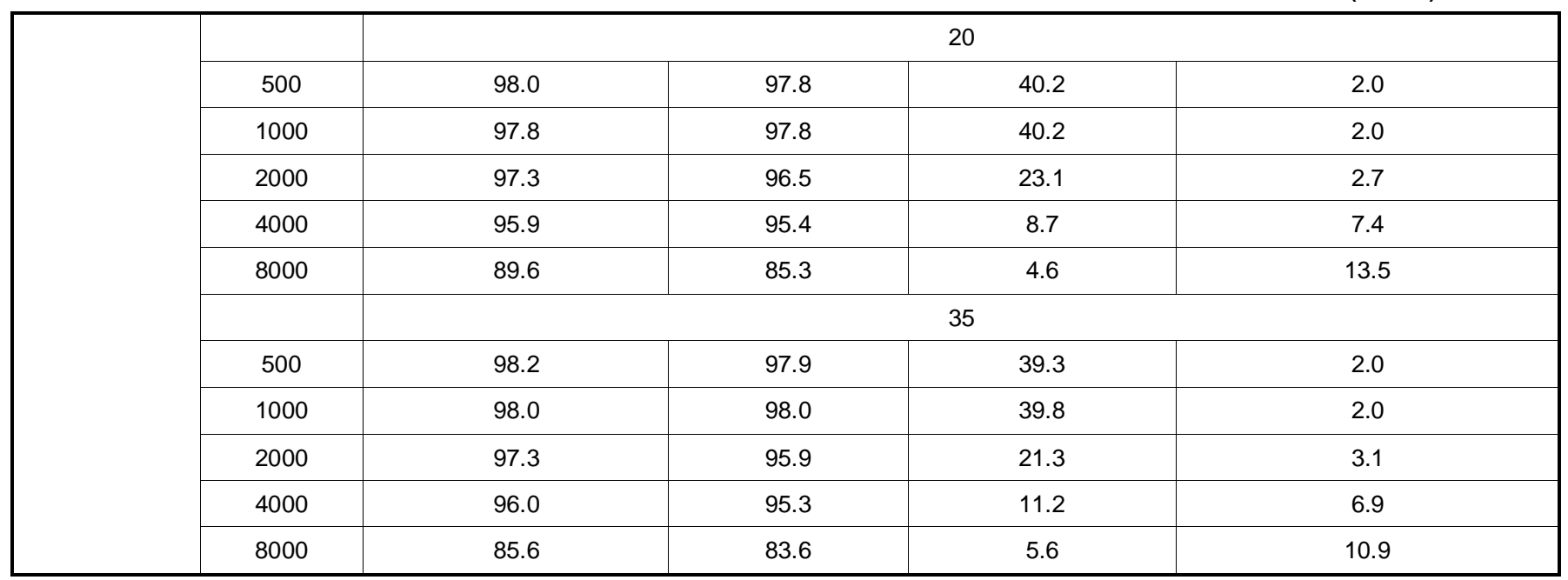

\subsection{Cost Estimates and Future Work}

The full cost of self-designed and fabricated photovoltaic-powered reverse osmosis (PV-RO) system presented in this work was evaluated with all ancillary components and manufacturing costs, but without shipping or installation. Referred to results listed in Table 1, with salinity concentration of $500 \mathrm{mg} / \mathrm{l}$ and $1000 \mathrm{mg} / \mathrm{l}$, the power needed to produce $1 \mathrm{~m}^{3}$ per day fresh water was $2.0 \mathrm{kWh} / \mathrm{m}^{3}$. Consequently, on the basis of PV power of $1.0 \mathrm{kWh}$ per day and equation 1 ,

Annual cost $=$ cost of item $\times \frac{(1+i)^{n} \times i}{(1+i)^{n}-i}$

Where $i$ : the annual interest rate, $n$ : the design life of item.

The total capital cost was estimated at $\mathrm{HK} \$$ 100,000 , where the cost of PV power system was about $\mathrm{HK} \$ 48,000$ and its annual cost was $\mathrm{HK} \$ 11,000$, and the cost of RO system was about HK\$ 52,000 and its annual cost was $\mathrm{HK} \$ 5,700$.

Taken 365 days as a year, the cost of producing 1 $\mathrm{m}^{3}$ per day fresh water was HK\$ 46 $((11,000+5,700) / 365=46)$. It is apparently higher than the present price (HK\$ 12 16) issued by Water Supplies Department, HK.

Therefore, for the successive future work, reducing the cost of desalination is vitally highlighted, such as longer performance or lifetime for the equipment of the PV-RO system, maintenance increasing, system efficiency improvement, electrical losses decreasing, etc.

\section{CONCLUSIONS}

The brackish water was filtered/desalinated by home-made photovoltaic-powered reverse osmosis (PV-RO) system successfully. The system produced clean drinking water from a variety of feed water, including high salinity (4000 and $8000 \mathrm{mg} / \mathrm{l})$ water. The amount of water recovery or ammonia and TDS removal depended directly on the working pressure for RO system. With increment of pressure, ammonia and TDS removal increased simultaneously. The final ammonia, and TDS removal was higher than 98\%, respectively. Moreover, the water recovery was up to $40.6 \%$ with the energy consumption of $2.0 \mathrm{kWh} / \mathrm{m}^{3}$.

\section{ACKNOWLEDGEMENTS}

The work is supported by the Strategic Research Grant (SRG) from City University of Hong Kong (Grant No.: 7004453).

\section{REFERENCES}

[1] Guo KW. Green Nanotechnology of Trends in Future Energy: A Review. Int J Energ Res 2011. http://dx.doi.org/10.1002/er.1928

[2] Guo KW. Membranes Coupled with Nanotechnology for Drinking Water: An Overview. Curr Biotech 2012; 1: 42-71. http://dx.doi.org/10.2174/2211550111201010042

[3] Charcosset C. A review of membrane processes and renewable energies for desalination. Desalination 2009, 245: 214-231. Bhubaneswari Parida, S. Iniyan, Ranko Goic. A review of solar photovoltaic technologies. Renew Sust Energ Rev 2011; 15: 1625-36. http://dx.doi.org/10.1016/j.rser.2010.11.032

[4] Richards BS, Schäfer AI. Photovoltaic-powered desalination system for remote Australian communities. Renew Energ 2003; 28: 2013-22.

http://dx.doi.org/10.1016/S0960-1481(03)00081-8 
[5] Al-Karaghouli A, Kazmerski LL. Energy consumption and water production cost of conventional and renewable-energypowered desalination processes. Renew Sust Energ Rev 2013; 24: 343-56.

http://dx.doi.org/10.1016/j.rser.2012.12.064

[6] Alghoul MA, Poovanaesvaran P, Mohammed MH, Fadhil AM, Muftah AF, Alkilani MM, Sopian K. Design and experimental performance of brackish water reverse osmosis desalination unit powered by $2 \mathrm{~kW}$ photovoltaic system. Renew Energ 2016; 93: 101-14.

http://dx.doi.org/10.1016/j.renene.2016.02.015

[7] Peterson EL, Gray SR. Effectiveness of desalination powered by a tracking solar array to treat saline bore water. Desalination 2012; 293: 94-103.

http://dx.doi.org/10.1016/j.desal.2012.02.029

[8] CLP Group (China Light and Power Co., Ltd. Traditional Chinese), https://www.clpgroup.com/en. 